\title{
Article
}

\section{PtSnNa/SUZ-4: An efficient catalyst for propane dehydrogenation}

\author{
Hualan Zhou a, Jingjing Gong a , Bolian Xu a, Shengcai Deng a , Yuanhua Ding b, Lei Yu a,b,*, \\ Yining Fan a,\# \\ a Key Laboratory of Mesoscopic Chemistry of MOE, Jiangsu Provincial Key Laboratory of Nanotechnology, School of Chemistry and Chemical Engineering, \\ Nanjing University, Nanjing 210046, Jiangsu, China \\ b Jiangsu Key Laboratory of Environmental Material and Environmental Engineering, School of Chemistry and Chemical Engineering, Yangzhou Universi- \\ ty, Yangzhou 225002, Jiangsu, China
}

\section{A R T I C L E I N F O}

Article history:

Received 16 November 2016

Accepted 17 December2016

Published 5 March 2017

\section{Keywords:}

SUZ-4 zeolite

PtSnNa catalyst

Propane dehydrogenation

Catalyst stability

Pt distribution

\begin{abstract}
A B S T R A C T
The structure and catalytic properties of PtSn catalysts supported on SUZ-4 and ZSM- 5 zeolite have been studied by using various experimental techniques including XRD, nitrogen adsorption, $\mathrm{NH}_{3}$-TPD, TG, $\mathrm{H}_{2}$-TPR and TPO techniques combined with propane dehydrogenation tests. It has been shown that SUZ-4-supported PtSnNa (PtSnNa/SUZ-4) was determined to be a better catalyst for propane dehydrogenation than conventional catalysts supported on ZSM-5, owing to its higher catalytic activity and stability. Dibenzothiophene poisoning experiments were performed to investigate the detailed structures of the two supported catalysts. The characterization of the two catalysts indicates that the distribution of Pt on the porous support affects the activity. In contrast to ZSM-5-supported catalysts, Pt particles on the PtSnNa/SUZ-4 are primarily dispersed over the external surface and are not as readily deactivated by carbon deposition. This is because that the strong acid sites of the SUZ-4 zeolite evidently prevented the impregnation of the Pt precursor $\mathrm{H}_{2} \mathrm{PtCl}_{6}$ into the zeolite. In contrast, the weak acid sites of the ZSM- 5 zeolite led to more of the precursor entering the zeolite tunnels, followed by transformation to highly dispersed Pt clusters during calcination. In the case of the PtSnNa/ZSM-5, the interactions between Sn oxides and the support were lessened, owing to the weaker acidity of the ZSM- 5 zeolite. The dispersed Sn oxides were therefore easier to reduce to the metallic state, thus decreasing the catalytic activity for hydrocarbon dehydrogenation.
\end{abstract}

(c) 2017, Dalian Institute of Chemical Physics, Chinese Academy of Sciences. Published by Elsevier B.V. All rights reserved.

\section{Introduction}

It is well reported that supported bi-component Pt-Sn catalysts can be employed in many reactions, including alkane dehydrogenation [1-3], hydrocarbon rearrangement [4], low temperature carbon monoxide oxidation [5], and alcohol electro-oxidation [6]. Among these applications, propane dehydro- genation is considered to be one of the most important petrochemical processes because of the rapidly growing demand for propylene [2,7-9]. Supported Pt-Sn catalysts have been widely used because of their high activities and environmentally friendly characteristics [1,2]. Aluminium oxide $\left(\mathrm{Al}_{2} \mathrm{O}_{3}\right)$ is the most common support for these materials, owing to its high surface area and acidity. However, $\mathrm{Al}_{2} \mathrm{O}_{3}$-supported Pt-Sn cata-

\footnotetext{
* Corresponding author. Tel: +86-13665295901; Fax: +86-514-879752444; E-mail: yulei@yzu.edu.cn \# Corresponding author. Tel: +86-25-83594620; Fax: +86-25-83317761; E-mail: ynfan@nju.edu.cn

This work was supported by the Jiangsu Planned Projects for Postdoctoral Research Funds (1301080C), NNSFC $(21202141,21173182)$, Key Science \& Technology Specific Projects of Yangzhou (YZ20122029), the Innovation Foundation of Yangzhou University (2015CXJ009).

DOI: 10.1016/S1872-2067(17)62750-5 | http://www.sciencedirect.com/science/journal/18722067 | Chin. J. Catal., Vol. 38, No. 3, March 2017
} 
lysts are deficient in terms of poor stability and lack of durability during recovery $[1,10,11]$. Thus, the development of novel supports to improve the stability of these catalysts is not only highly desirable but also timely.

In recent years, zeolites such as SUZ-4 and ZSM-5 have been found to be good supports because of their high surface areas, good thermal stabilities, large pore volumes and tunable acidity [12-14]. SUZ-4 is a new type of synthetic zeolite patented by the British Petroleum Company in 1992. In the three dimensional topological structure of this material, straight ten-membered channels intersect with two eight-membered channels at an angle of approximately $74^{\circ}$, which is similar to the structure of ZSM-5 zeolite $[15,16]$. SUZ-4-supported catalysts have been widely used in many processes, such as the conversion of $n$-hexane [16], the synthesis of dimethyl ether from methanol [17], and the elimination of nitrogen oxides [18]. However, there have not yet been any reports concerning the application of SUZ-4-supported catalysts to propane dehydrogenation, while ZSM-5-supported catalysts have attracted significant attention in this regard $[13,19]$. In contrast to $\gamma-\mathrm{Al}_{2} \mathrm{O}_{3}$, the three-dimensional microporous ZSM- 5 zeolite has a well-defined, ten-membered, ring-crossed channel system that prevents the formation of large hydrocarbon molecules, thus improving the catalyst's stability [13]. Recently, Zhou's group [20] investigated propane dehydrogenation over ZSM-5-supported Pt-Sn catalysts and found that the propylene selectivity was significantly improved by introducing promoters to neutralize the support acidity. The addition of hydrogen to the reaction system effectively inhibited the cracking of propane to $\mathrm{C} 1$ and $\mathrm{C} 2$ products and also reduced carbon deposition on the catalyst surface, thus improving both the dehydrogenation selectivity and catalytic stability [21]. Despite this, the ZSM-5-based catalysts were still easily deactivated by carbon deposition under the chosen reaction conditions. To resolve this issue, our own group developed the SUZ-4-supported catalyst PtSnNa/SUZ-4, which afforded a $20 \%$ propylene yield. Although propylene can be obtained in similar 18\%-23\% yields by increasing the Sn loading when using a PtSn/ZSM-5 catalyst [22], our catalyst has the advantage of being more robust and undergoing very little deactivation due to carbon deposition.

\section{Experimental}

\subsection{Catalyst preparation}

An SUZ- 4 zeolite with the molar ratio $\mathrm{SiO}_{2} / \mathrm{Al}_{2} \mathrm{O}_{3}=21$ and a ZSM-5 zeolite with the molar ratio $\mathrm{SiO}_{2} / \mathrm{Al}_{2} \mathrm{O}_{3}=20$ were prepared by methods previously described in the literature $[23,24]$. In each case, the resulting solid phase was filtered, washed with distilled water several times, dried at $110{ }^{\circ} \mathrm{C}$ for $12 \mathrm{~h}$ and then calcined at $550{ }^{\circ} \mathrm{C}$ for $4 \mathrm{~h}$. This was followed by $\mathrm{NH}_{4}{ }^{+}$exchange in aqueous $\mathrm{NH}_{4} \mathrm{Cl}(1 \mathrm{~mol} / \mathrm{L})$. H-SUZ-4 and H-ZSM-5 were obtained by calcining the ammonium forms of SUZ-4 and ZSM- 5 at $550{ }^{\circ} \mathrm{C}$ for $4 \mathrm{~h}$. PtSnNa catalysts supported on either the SUZ-4 or the ZSM-5 zeolite $(\mathrm{Pt}=0.5 \%, \mathrm{Sn}=2.0 \%$, $\mathrm{Na}=1.0 \%$ ) were prepared by sequentially impregnating the
H-SUZ-4 or H-ZSM-5 with an aqueous mixture of $\mathrm{H}_{2} \mathrm{PtCl}_{6}$ and $\mathrm{SnCl}_{4}\left(\mathrm{H}_{2} \mathrm{PtCl}_{6}=5 \mathrm{mg} / \mathrm{mL}, \mathrm{SnCl}_{4}=5.85 \mathrm{mg} / \mathrm{mL}\right)$ and with aqueous $\mathrm{NaCl}(0.5 \mathrm{~mol} / \mathrm{L})$. The impregnated samples were dried at $110{ }^{\circ} \mathrm{C}$ for $4 \mathrm{~h}$, calcined at $520{ }^{\circ} \mathrm{C}$ for $4 \mathrm{~h}$, and then dechlorinated in air containing water vapor at $530^{\circ} \mathrm{C}$ for $4 \mathrm{~h}$.

\subsection{Catalyst characterization}

The powder X-ray diffraction (XRD) patterns of all samples were obtained with a Philips X'pert pro diffractometer using $\mathrm{Cu}$ $K_{\alpha}$ radiation at $40 \mathrm{kV}$ and $40 \mathrm{~mA}$, from $5^{\circ}$ to $50^{\circ}$. Surface areas were calculated by the BET method based on $\mathrm{N}_{2}$ adsorption isotherms recorded at the temperature of liquid nitrogen using a Micromeritics ASAP2010 analyzer. The samples were degassed at $300{ }^{\circ} \mathrm{C}$ and $0.133 \mathrm{~Pa}$ prior to analysis, after which isotherms were acquired at $-196{ }^{\circ} \mathrm{C}$. $\mathrm{NH}_{3}$-TPD profiles of the specimens were obtained in a flow-type fixed-bed reactor at ambient pressure. The catalysts were pre-treated at $500{ }^{\circ} \mathrm{C}$ for $2 \mathrm{~h}$ under an Ar flow. The $\mathrm{NH}_{3}$ adsorption temperature was 100 ${ }^{\circ} \mathrm{C}$, and the temperature was raised at a rate of $10{ }^{\circ} \mathrm{C} / \mathrm{min}$. The desorbed $\mathrm{NH}_{3}$ was detected by a gas chromatograph (GC) equipped with a thermal conductivity detector (TCD).

$\mathrm{H}_{2}$ chemisorption on the supported PtSnNa catalysts was assessed both before and after the propane dehydrogenation reaction according to a previously described procedure [25]. Each of the catalysts was reduced in a $\mathrm{H}_{2}$ flow at $500{ }^{\circ} \mathrm{C}$ for $2 \mathrm{~h}$ and then out-gassed in an Ar flow at $540{ }^{\circ} \mathrm{C}$ for $2 \mathrm{~h}$ before $\mathrm{H}_{2}$ chemisorption measurements.

The amount of carbonaceous material deposited on each catalyst during the propane dehydrogenation reaction was measured using thermo-gravimetric (TG) analysis (STA 449C-Thermal star 300 TA-MS apparatus). Catalyst samples (each approximately $0.02 \mathrm{~g}$ ) obtained after a 10 -h reaction were heated from room temperature to $900{ }^{\circ} \mathrm{C}$ in $\mathrm{O}_{2}$ (at 25 $\mathrm{mL} / \mathrm{min}$ ) at a heating rate of $10{ }^{\circ} \mathrm{C} / \mathrm{min}$, and the amounts of coke on the specimens was calculated from the resulting TG curves.

Temperature-programmed oxidation (TPO) was determined with the same apparatus as used for the $\mathrm{H}_{2}$ chemisorption experiments. An approximately 0.1-g sample was placed in a quartz reactor and then heated to $800{ }^{\circ} \mathrm{C}$ in a mixture of $\mathrm{O}_{2}$ (at $3.0 \mathrm{~mL} / \mathrm{min}$ ) and $\mathrm{Ar}$ (at $30 \mathrm{~mL} / \mathrm{min}$ ) at a heating rate of $10{ }^{\circ} \mathrm{C} / \mathrm{min}$. Temperature-programmed reduction (TPR) was performed using the same apparatus employed during the TPO assessments. In these trials, approximately 0.1 -g samples were placed in a quartz reactor and subsequently heated in a flow of $5 \% \mathrm{H}_{2}-95 \% \mathrm{Ar}$ (at $20 \mathrm{~mL} / \mathrm{min}$ ) at a heating rate of $10^{\circ} \mathrm{C} / \mathrm{min}$.

Purposely poisoned catalysts (containing $0.02 \% \mathrm{~S}$ ) were prepared by impregnating the reduced PtSnNa/SUZ-4 or PtSnNa/ZSM-5 catalysts with an ethanol solution of dibenzothiophene $(0.2 \mathrm{mg} / \mathrm{mL})$, followed by flushing with nitrogen for 1 to $2 \mathrm{~h}$ to evaporate residual ethanol and drying at $110^{\circ} \mathrm{C}$ for $4 \mathrm{~h}$.

All catalysts were reduced in $\mathrm{H}_{2}$ at $500{ }^{\circ} \mathrm{C}$ for $2 \mathrm{~h}$ before catalytic evaluation. The propane dehydrogenation reaction was carried out in a quartz tubular micro-reactor under 
Table 1

Propane conversion, propylene selectivity and propylene yield values following a $10 \mathrm{~h}$ reaction for samples with different sodium ion contents.

\begin{tabular}{lcccc}
\hline Entry & Catalyst $^{\mathrm{a}}$ & $\begin{array}{c}\text { Propane } \\
\text { conversion } \\
(\mathrm{mol} \%)\end{array}$ & $\begin{array}{c}\text { Propylene } \\
\text { selectivity } \\
\text { (mol \%) }\end{array}$ & $\begin{array}{c}\text { Propylene } \\
\text { yield } \\
\text { (mol \%) }\end{array}$ \\
\hline 1 & $\mathrm{PtSn} / \mathrm{SUZ}-4$ & 12.8 & 84.2 & 10.8 \\
2 & $\mathrm{PtSnNa}(0.5) / S U Z-4$ & 19.7 & 93.0 & 18.3 \\
3 & $\mathrm{PtSnNa}(1.0) / S U Z-4$ & 20.5 & 92.4 & 18.9 \\
4 & $\mathrm{PtSnNa}(2.0) / S U Z-4$ & 8.9 & 93.5 & 8.1 \\
\hline
\end{tabular}

a Values in parentheses indicate the sodium ion content by mass fraction (\%).

reaction conditions of $0.1 \mathrm{MPa}, 590{ }^{\circ} \mathrm{C}, \mathrm{C}_{3} \mathrm{H}_{8} / \mathrm{H}_{2}=1 / 3$ (molar ratio) and a propane weight hourly space velocity (WHSV) of 3.0-1. The reaction products $\left(\mathrm{C}_{3} \mathrm{H}_{6}, \mathrm{CH}_{4}, \mathrm{C}_{2} \mathrm{H}_{6}\right.$ and $\left.\mathrm{C}_{2} \mathrm{H}_{4}\right)$ were analyzed by an online GC (Shimadzu GC-14A, Japan) with a TCD and an $\mathrm{Al}_{2} \mathrm{O}_{3}$ packed column.

\section{Results and discussion}

\subsection{Propane dehydrogenation}

A series of catalysts with different sodium ion contents were prepared and tested for their activity during propane dehydrogenation. The addition of sodium ions improved both the propane conversion and the propylene selectivity (entries 2,3 vs. 1), as shown in Table 1. A sodium content of $1.0 \%$ was found to be optimal (entries 3 vs. 2,4 ) and so was used in the following experiments. It is known that the by-products of this reaction are methane and ethane due to the cracking of propane or propylene on catalyst acid sites. As shown in Fig. 1, the pure zeolite catalysts H-SUZ-4 and H-ZSM-5 exhibited high initial reaction activities but very poor stability, as reflected in the rapidly decreased propane conversions (Fig. 1(a), curves (1) and (2)). In addition, the H-SUZ-4 and H-ZSM-5 both showed very low propylene selectivity (Fig. 1(b), curves (1) and (2)), which is an even more crucial property for industrial production. The evident deactivation and low propylene selectivity were likely due to the excessive concentrations of acid sites on these materials, leading to carbon deposits and undesirable cracking reactions, respectively. The PtSnNa-based catalysts, including both PtSnNa/SUZ-4 and PtSnNa/ZSM-5, were much more advanced. Between these two, the PtSnNa/SUZ-4 was found to be superior based on its higher stability and propylene selectivity (Fig. 1(a), curves (3) vs. (4); Fig. 1(b), curves (3) vs. (4)). Moreover, the PtSnNa/SUZ-4 afforded the highest propylene yields of up to $20 \%$ (Fig. 1(c), curves (3) vs. $(1,2)$ and $(4.5)$ ). It should be noted that, even without a catalyst, some small amount of propane was still transformed, although with poor selectivity, because of cracking reactions (Figs. 1(a-c), curves (5)).

\subsection{Structure and surface properties of the catalysts}

Each of the specimens was assessed by XRD. As shown in Fig. 2, no crystalline phase signals attributable to Pt, Sn or Na were observed after the impregnation, calcination or hydrogen reduction steps, possibly due to the low concentrations and/or the high dispersion states of these metals (Fig. 2, curves (2) and (5)) [18]. Moreover, compared with the original structures of the SUZ-4 and ZSM-5 zeolite supports, the XRD patterns of the supported catalysts do not show any characteristic changes (Fig. 2, curves (1) vs. (2); (4) vs. (5)). After the propane dehydrogenation reaction was performed for $10 \mathrm{~h}$, the signals of the SUZ-4 and ZSM- 5 zeolites are also observed in the XRD patterns of the catalysts, as shown in Fig. 2, curves (3) and (6), indicating that the supports were stable during the reaction.

Fig. 3 presents the nitrogen adsorption-desorption isotherms of the catalysts. The H-SUZ-4 and H-ZSM- 5 generated types I and IV adsorption-desorption isotherms, respectively (curves (2) and (4)), corresponding to microporous and mesoporous materials. Furthermore, the adsorptiondesorption isotherms of the supported catalysts are similar to those of the supports (curves (1) vs. (2), (3) vs. (4)). This result indicates that the uniform pore structures of the supports were maintained after loading of the $\mathrm{Pt}, \mathrm{Sn}$ and $\mathrm{Na}$ components.
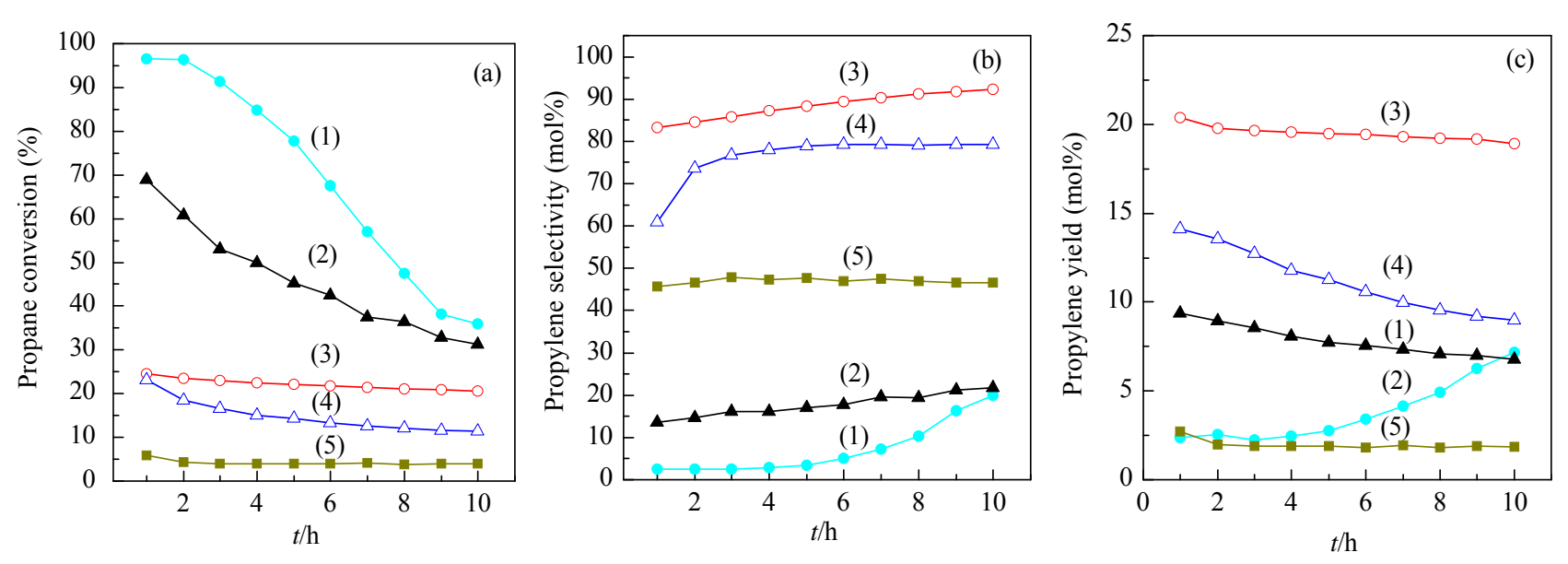

Fig. 1. (a) Propane conversion, (b) propylene selectivity and (c) propylene yield over time for different catalysts. (1) H-SUZ-4; (2) H-ZSM-5; (3) PtSn$\mathrm{Na} / S U Z-4$; (4) PtSnNa/ZSM-5; (5) without a catalyst. Reaction conditions: $590{ }^{\circ} \mathrm{C}, \mathrm{H}_{2} / \mathrm{C}_{3} \mathrm{H}_{8}=1 / 3$ (molar ratio), $m$ (cat.) $=0.3 \mathrm{~g}, \mathrm{WHSV}=3.0 \mathrm{~h}{ }^{-1}$. 


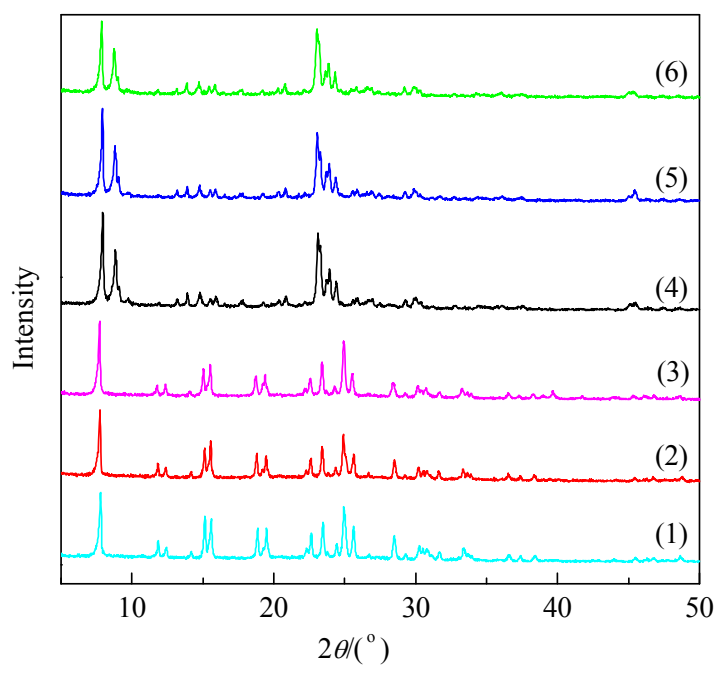

Fig. 2. XRD patterns of the catalysts. (1) H-SUZ-4; (2) PtSnNa/SUZ-4; (3 PtSnNa/SUZ-4 after reaction for $10 \mathrm{~h}$; (4) H-ZSM-5, (5) PtSnNa/ZSM-5; (6) PtSnNa/ZSM-5 after reaction for $10 \mathrm{~h}$.

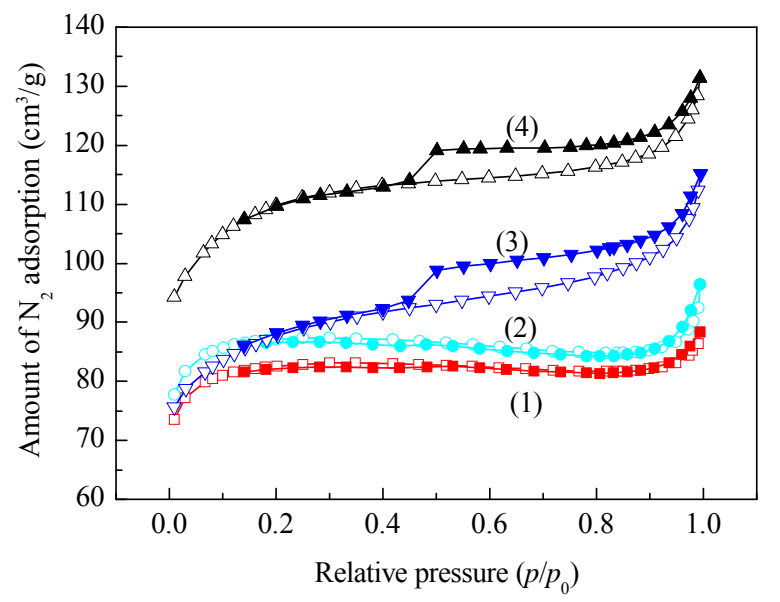

Fig. 3. Nitrogen adsorption-desorption isotherms of the catalysts. (1) PtSnNa/SUZ-4; (2) H-SUZ-4; (3) PtSnNa/ZSM-5; (4) H-ZSM-5.

Table 2 summarizes the characterization data for different catalysts. It is evident that the pore volumes $\left(V_{\mathrm{p}}\right)$ and surface areas of the supported catalysts were decreased (entry 2 vs. 1; entry $4 v s .3$ ) and that these values were further reduced following the reaction (entries 2 and 4). These results can possibly be attributed to blocking of the support pores by the Pt or by coke. Compared with the PtSnNa/ZSM-5, the $V_{\mathrm{p}}$ of the PtSn$\mathrm{Na} / \mathrm{SUZ}-4$ after the reaction was decreased by a smaller amount, clearly showing that the pores in this new material were less likely to be blocked by coke deposition. The amounts

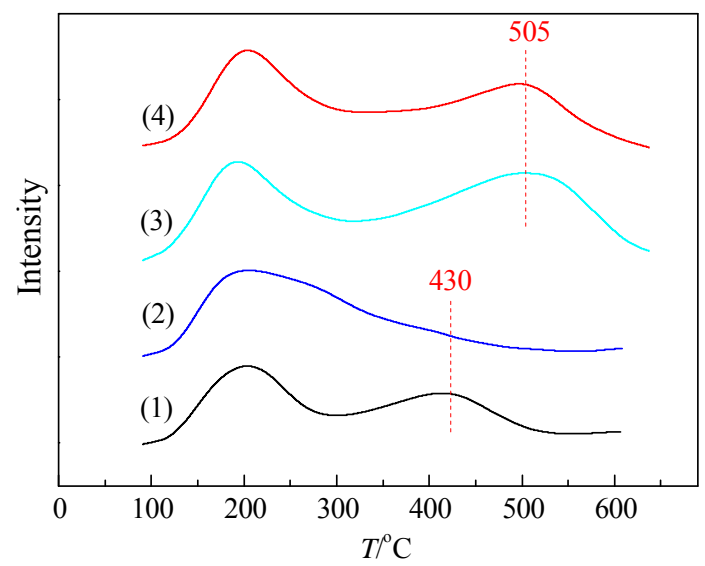

Fig. 4. $\mathrm{NH}_{3}$-TPD profiles of the catalysts. (1) H-ZSM-5; (2) PtSnNa/ZSM-5; (3) H-SUZ-4; (4) PtSnNa/SUZ-4.

of coke deposited on each catalyst during the reaction could be determined from TG analysis and are presented in Table 2. The pore sizes of both catalysts were increased following the reaction. In addition, the $\mathrm{H}_{2}$ uptake of the fresh PtSnNa/SUZ-4 catalyst was close to that of the fresh PtSnNa/ZSM-5 catalyst, which is consistent with their similar catalyst activities in the initial reaction stage (Fig. 1(a)). Compared with the PtSnNa/SUZ-4, the $\mathrm{H}_{2}$ uptake of the PtSnNa/ZSM-5 catalyst was decreased to a greater extent ( $c a .36 \%$ ) after coke deposition (9 wt.\%). However, the differences in the performance of these two catalysts during propane dehydrogenation cannot be attributed to the insignificant difference in the deposited coke amounts. These results indicate that there might be some other reasons for the rapid deactivation of the PtSnNa/ZSM-5 catalyst.

To obtain more information regarding the reaction mechanism, the acidities of the different catalysts were examined by $\mathrm{NH}_{3}$ temperature-programmed desorption (TPD). The $\mathrm{NH}_{3}$-TPD profiles are displayed in Fig. 4 while the detailed data are given in Table 3. Here the acid amount is proportional to the corresponding desorption peak area. The different crystal structures of the H-ZSM-5 and H-SUZ-4 zeolite resulted in variations (both in strength and amount) in the surface acidity of the supports, and loading with PtSnNa led to a more obvious change. Two $\mathrm{NH}_{3}$ desorption peaks appear in these TPD profiles. The first signal, in the range of 190 to $200{ }^{\circ} \mathrm{C}$, is attributed to weak acid absorption, while the second peak, at 420 to $520{ }^{\circ} \mathrm{C}$, results from strong acid sites (Fig. 4) [26,27]. The TPD profile of the PtSnNa/ZSM-5 is quite different from that of the H-ZSM-5. A broadened peak showing stronger $\mathrm{NH}_{3}$ desorption at low temperature appears, while the strong acid

Table 2

The pore volumes, surface areas, pore sizes, $\mathrm{H}_{2}$ uptakes and the amounts of coke deposited on the different catalysts a.

\begin{tabular}{|c|c|c|c|c|c|c|}
\hline Entry & Catalyst & $V_{\mathrm{P}} /\left(\mathrm{cm}^{3} / \mathrm{g}\right)$ & $A_{\mathrm{BET}} /\left(\mathrm{m}^{2} / \mathrm{g}\right)$ & $\mathrm{D} / \mathrm{nm}$ & $\mathrm{H} /(\mathrm{mL} / \mathrm{g})$ & $\mathrm{C} /(\mathrm{wt} \%)$ \\
\hline 1 & H-SUZ-4 & 0.14 & 291 & 1.89 & - & - \\
\hline 2 & PtSnNa/SUZ-4 & $0.13(0.11)$ & $277(213)$ & $1.92(2.15)$ & $22(19)$ & 8 \\
\hline 3 & H-ZSM-5 & 0.20 & 313 & 2.06 & - & - \\
\hline 4 & PtSnNa/ZSM-5 & $0.17(0.13)$ & 297 (239) & $2.10(2.29)$ & $25\left(16,24^{b}\right)$ & 9 \\
\hline
\end{tabular}

${ }^{\mathrm{a}}$ Data in parentheses are the value for catalysts after a 10 -h reaction. ${ }^{\mathrm{b}} \mathrm{H}_{2}$ uptake of the catalyst after partial oxidation trials (vide infra, Fig. $6(\mathrm{~b})$ ). 
Table 3

The acid amounts calculated from the corresponding desorption peak areas in Fig. 4 for different catalysts.

\begin{tabular}{lccccc}
\hline \multirow{2}{*}{ Entry } & Curve in & \multirow{2}{*}{ Catalyst } & \multicolumn{3}{c}{ Relative acid amount } \\
\cline { 4 - 6 } & Fig. 4 & & Weak & Strong & Total \\
\hline 1 & $(1)$ & H-ZSM-5 & 283 & 163 & 446 \\
2 & $(2)$ & PtSnNa/ZSM-5 & 781 & 0 & 781 \\
3 & $(3)$ & H-SUZ-4 & 191 & 516 & 707 \\
4 & $(4)$ & PtSnNa/SUZ-4 & 354 & 297 & 651 \\
\hline
\end{tabular}

absorption signal is absent (Fig. 4, curves (1) vs. (2)), indicating that the addition of the Sn and Na promoters might preferentially neutralize the strong acid sites. Similar phenomena have been observed for PtSnNa/AlSBA-15 [28]. The total number of acid sites was increased when metals were loaded on the ZSM-5-supported catalysts (Table 3, entries 2 vs. 1), but in the case of SUZ-4-supported catalysts, the acid sites decreased with the loading of PtSnNa (Table 3, entries 4 vs. 3). It should be noted that the acidity strength of the H-ZSM-5 catalyst was much weaker than that of the H-SUZ-4 catalyst. This is in agreement with a report that zeolites with mutually intersecting 10-ring channels have been found to possess lower acid strengths than those with intersecting 10- and 8-ring channels [29]. In addition, compared with the H-SUZ-4, the total acid sites of the PtSnNa/SUZ-4 decreased more severely, which benefitted the propane dehydrogenation [30]. Because excessive acidity can lead to the undesirable cracking reaction, the PtSnNa/ZSM-5 catalyst showed lower propylene selectivity than the PtSnNa/SUZ-4 (Fig. 1(b), curves (4) vs. (3)).

\subsection{Dibenzothiophene poisoning experiments}

To investigate the detailed structures of these materials, experiments were performed using dibenzo $[b, d]$ thiophene-poisoned catalysts. As can be seen from Fig. 5, both the PtSnNa/SUZ-4 and PtSnNa/ZSM-5 showed decreased activity after being treated with dibenzo $[b, d]$ thiophene (curves (1) vs. (4) and (2) vs. (3)). However, the decrease in the activity of the PtSnNa/SUZ-4 was much more obvious than that of the PtSnNa/ZSM-5 (curves (1) vs. (2)). Because dibenzo $[b, d]$ thiophene has a molecule diameter (ca. $0.8 \mathrm{~nm}$ ) larger than the widths of the tunnels in both the SUZ-4 and ZSM-5 zeolite (ca. $0.46-0.56 \mathrm{~nm}$ ) [23,31,32], the dibenzo $[b, d]$ thiophene molecules could only contact the surface Pt, while the Pt particles inside the tunnels remained untouched. Thus, these experiments clearly show that a greater proportion of the Pt was dispersed on the zeolite surface of the $\mathrm{PtSnNa} / \mathrm{SUZ}-4$ than on the PtSnNa/ZSM-5. The strong acid sites of the SUZ-4 zeolite evidently prevented the impregnation of the Pt precursor $\mathrm{H}_{2} \mathrm{PtCl}_{6}$ into the zeolite. In contrast, the weak acid sites of the ZSM-5 zeolite (Table 3, entries 2 vs. 4) led to more of the precursor entering the zeolite tunnels, followed by transformation to highly dispersed Pt clusters during calcination [33]. Thus, more Pt clusters were dispersed inside the tunnels in the PtSnNa/ZSM-5 than in the PtSnNa/SUZ-4. This is in accordance with the observation that the $V p$ of the PtSnNa/ZSM-5 declined to a greater extent than that of the

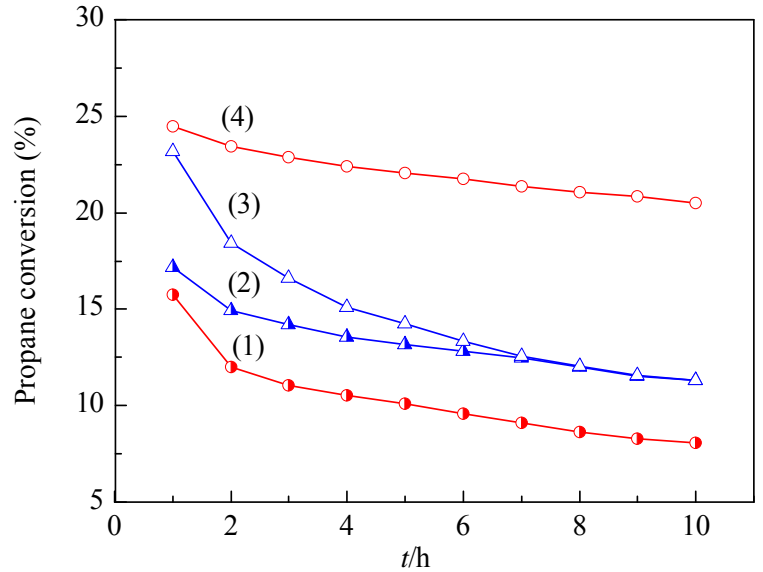

Fig. 5. Conversion as a function of reaction time for different catalysts before and after dibenzothiophene poisoning. (1) PtSnNa/SUZ-4 after poisoning; (2) PtSnNa/ZSM-5 after poisoning; (3) fresh PtSnNa/ZSM-5; (4) fresh PtSnNa/SUZ-4. Poisoning conditions: $\mathrm{S}=0.02 \%$ in an ethanol solution of dibenzothiophene, flushed with nitrogen. Reaction conditions: $590{ }^{\circ} \mathrm{C}, \mathrm{H}_{2} / \mathrm{C}_{3} \mathrm{H}_{8}=1 / 3$ (molar ratio), $m$ (cat.) $=0.3 \mathrm{~g}$, WHSV $=3.0$ $\mathrm{h}^{-1}$.

PtSnNa/SUZ-4 during the reaction (Table 2, entries 4 vs. 2).

The varying Pt distributions inside and outside the two supports could have generated the different carbon deposition distributions. The TPO profiles of the used catalysts are presented in Fig. 6(a). In the case of the PtSnNa/ZSM-5, two successive peaks representing different carbon deposits on the surface are observed (Fig. 6(a), curve (2)). Partial oxidation experiments (POE) that removed carbon deposits at $520{ }^{\circ} \mathrm{C}$ were found to reactivate the catalyst, leading to increased propylene selectivity while the propane conversion remained stable (Fig. 6(b), curves (1) vs. (2), (3) vs. (4)). These data indicate that the carbon deposits responsible for the $590{ }^{\circ} \mathrm{C}$ peak (Fig. 6(a)) did not affect the catalytic activity. The $\mathrm{H}_{2}$ uptake (Table 2, entry 4) of the PtSnNa/ZSM-5 after the POE was close to that of the fresh material, a result that is in good agreement with the approximate propane conversion values in Fig. 6(b). Thus, the peak at $520{ }^{\circ} \mathrm{C}$ is attributed to carbon deposits that covered the catalytic Pt, while the $590{ }^{\circ} \mathrm{C}$ peak is due to the carbon deposits located on the zeolite surface. These conclusions agree with reports in the literature [22]. Finally, based on the previous pre-treatment results, the $520{ }^{\circ} \mathrm{C}$ peak can be ascribed to the coke on the surfaces of Pt nanoparticles located in the zeolite tunnels. In the case of the PtSnNa/SUZ-4 (Fig. 6(a), curve (1)), the TPO profile shows only one type of coke (at $630{ }^{\circ} \mathrm{C}$ ), located on the zeolite surface. Carbon deposits that cover the Pt can deactivate the catalyst and so, following the 10-h reaction, both the $\mathrm{H}_{2}$ uptake (Table 2, entry 4) and the activity of the PtSnNa/ZSM-5 were significantly decreased.

\subsection{Interactions of catalyst components}

Previous studies have indicated that the interactions between the Pt, Sn and support are important factors affecting the state of the Sn component, the dispersion of the Pt and the dehydrogenation performance of the catalyst $[34,35]$. In the 

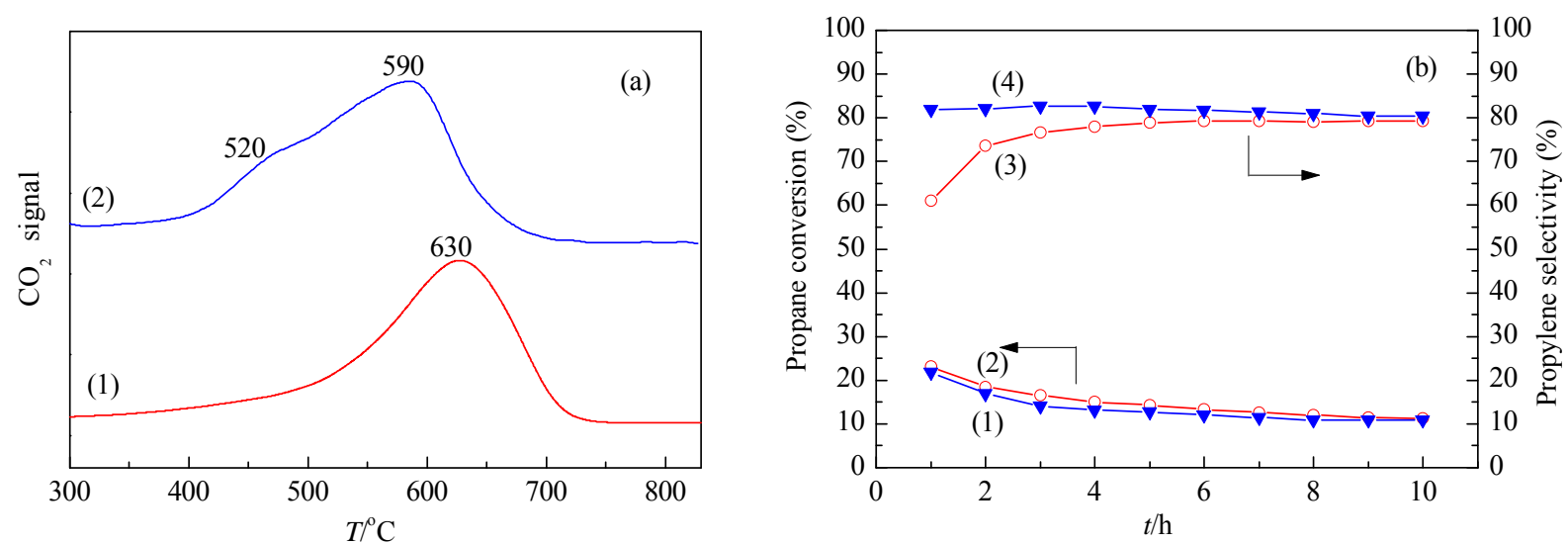

Fig. 6. (a) TPO profiles of the catalysts. (1) PtSnNa/SUZ-4; (2) PtSnNa/ZSM-5. (b) Reaction activity of the PtSnNa/ZSM-5 catalyst before and after POE trials. (1) Propane conversion after POE; (2) Propane conversion before POE; (3) Propylene selectivity before POE; (4) Propylene selectivity after POE.

case of catalysts with high levels of added metal components but low dispersion, it is difficult to obtain useful information about the catalyst active phase structure based on characterizations with XRD and X-ray photoelectron spectroscopy. To further assess the interaction of each component in the PtSnNa catalyst, TPR with $\mathrm{H}_{2}$ was performed. As shown in Fig. 7, a broad but weak reduction peak was observed at $350{ }^{\circ} \mathrm{C}$ for the Pt/SUZ-4 sample, indicating that the majority of the Pt(II) was oxidized to Pt(0) during heating (Fig. 7, curve (1)) [36]. In contrast, the Sn/SUZ-4 generated two reductive peaks. The peak at $300{ }^{\circ} \mathrm{C}$ is attributed to the reduction of Sn(IV) to $\mathrm{Sn}$ (II), while the peak at $520{ }^{\circ} \mathrm{C}$ clearly indicates the reduction of Sn(IV) or $\mathrm{Sn}(\mathrm{II})$ to $\mathrm{Sn}(0)$ (Fig. 7, curve (2)). The reduction of the Sn component was evidently much easier following the addition of $\mathrm{Pt}$, as the signals produced by the PtSn/SUZ-4 were moved to lower temperatures (Fig. 7, curves (3) vs. (2)). Compared with the PtSn/SUZ-4, the $\mathrm{Sn}(\mathrm{II})$ to $\mathrm{Sn}(0)$ reductive peak of the $\mathrm{PtSnNa} / \mathrm{SUZ}-4$ was increased in intensity and situated at a lower temperature $\left(400^{\circ} \mathrm{C}\right)$, demonstrating that the addition of $\mathrm{Na}$ reduced the interactions between the Sn species and the support, and promoted the reduction of Sn (Fig. 7, curves (4) vs.

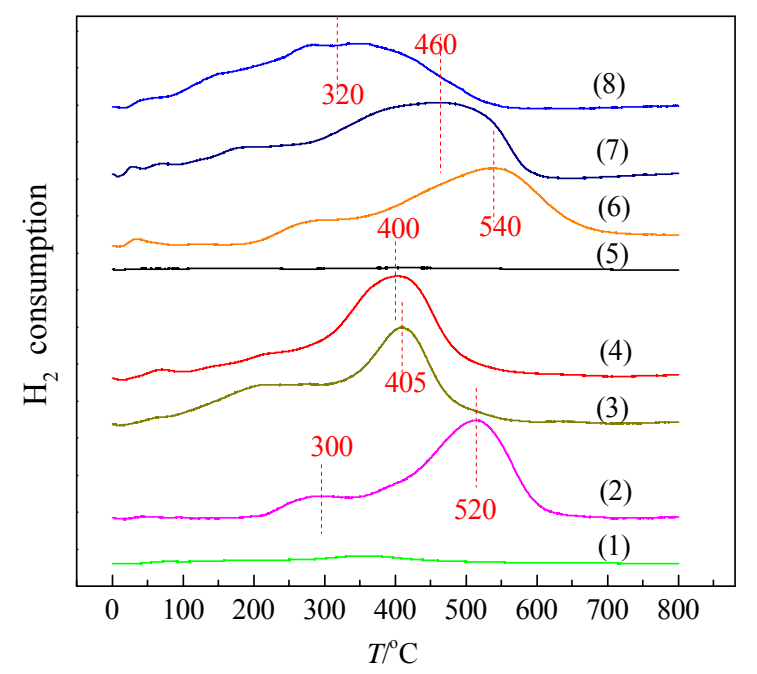

Fig. 7. TPR profiles of the catalysts. (1) Pt/SUZ-4; (2) Sn/SUZ-4; (3) PtSn/SUZ-4; (4) PtSnNa/SUZ-4; (5) Pt/ZSM-5; (6) Sn/ZSM-5; (7) PtSn/ZSM-5; (8) PtSnNa/ZSM-5.
(3)). The ZSM-5 supported catalysts exhibited similar behavior (Fig. 7, curves (5-8)). However, as shown by the much greater peak area in curve (8), the higher valency Sn on the ZSM-5 was reduced to metallic $\mathrm{Sn}$ much more easily, likely because of the weaker acidity of the PtSnNa/ZSM-5, as shown by the $\mathrm{NH}_{3}-\mathrm{TPD}$ profiles (Fig. 4). The coverage of surface Pt by metallic Sn species in the Pt-Sn alloys may lead to decreased $\mathrm{H}_{2}$ uptake and lower catalytic activity during hydrocarbon dehydrogenation $[37,38]$.

\section{Conclusions}

PtSnNa/SUZ-4 was found to exhibit higher activity and improved stability compared with PtSnNa/ZSM-5 during propane dehydrogenation. Variations in the Pt distribution were likely the main reason for the different performance of the two catalysts. The higher catalytic activity and stability of the PtSnNa/SUZ-4 catalyst can possibly be attributed to a greater quantity of $\mathrm{Pt}$ on its external surfaces, and the minimal deactivation of this Pt by carbon deposition that blocked the zeolite pores. In the case of the PtSnNa/ZSM-5, the interactions between Sn oxides and the support were lessened because of the weaker acidity of the ZSM-5 zeolite. The dispersed Sn oxides were therefore easier to reduce to the metallic state, thus decreasing the catalytic activity for hydrocarbon dehydrogenation.

\section{Acknowledgments}

We thank the High Level Talent Support Project of Yangzhou University for financial support. We thank Dr. Lei Fan for suggestions. We thank the analysis centre of Yangzhou University for assistances.

\section{References}

[1] X. Liu, W. Z. Lang, L. L. Long, C. L. Hu, L. F. Chu, Y. J. Guo, Chem. Eng. J., 2014, 247, 183-192.

[2] A. Iglesias-Juez, A. M. Beale, K. Maaijen, T. C. Weng, P. Glatzel, B. M. Weckhuysen, J. Catal., 2010, 276, 268-279.

[3] S. Sokolov, M. Stoyanova, U. Rodemerck, D. Linke, E. V. Kon- 


\section{Graphical Abstract}

Chin. J. Catal., 2017, 38: 529-536 doi: 10.1016/S1872-2067(17)62750-5

\section{PtSnNa/SUZ-4: An efficient catalyst for propane dehydrogenation}

Hualan Zhou, Jingjing Gong, Bolian Xu, Shengcai Deng, Yuanhua Ding, Lei Yu*, Yining Fan*

Nanjing University; Yangzhou University

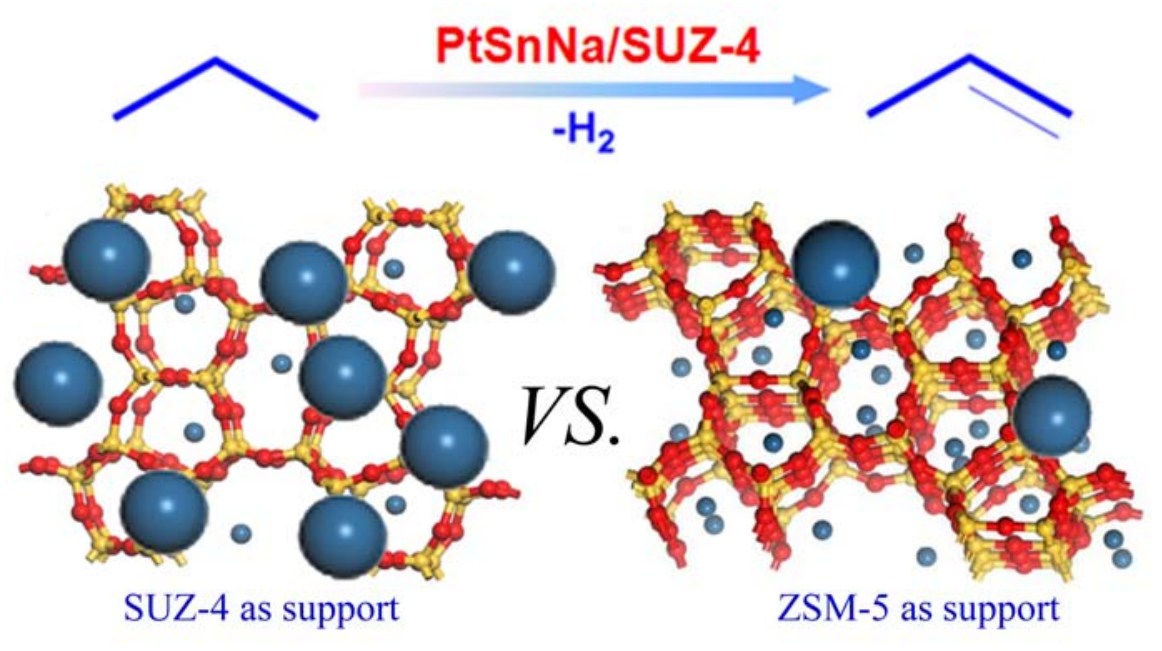

Pt crystal on the surface

- Pt crystal inside the channel

The new catalyst PtSnNa/SUZ-4 was found to be superior to PtSnNa/ZSM-5 during propane dehydrogenation, at least partly because Pt particles on the PtSnNa/SUZ-4 are primarily dispersed over its external surface and so are not deactivated by carbon deposition.

dratenko, J. Catal., 2012, 293, 67-75.

[4] T. Fujikawa, F. H. Ribeiro, G. A. Somorjai, J. Catal., 1998, 178, 58-65.

[5] B. C. Vicente, R. C. Nelson, J. Singh, S. L. Scott, J. A. van Bokhoven, Catal. Today, 2011, 160, 137-143.

[6] N. Erini, R. Loukrakpam, V. Petkov, E. A. Baranova, R. Z. Yang, D. Teschner, Y. H. Huang, S. R. Brankovic, P. Strasser, ACS Catal., 2014, 4, 1859-1867.

[7] M. S. Kumar, D. Chen, J. C. Walmsley, A. Holmen, Catal. Commun., 2008, 9, 747-750.

[8] Z. Nawaz, X. P. Tang, J. Zhu, F. Wei, S. Naveed, Chin. J. Catal., 2009, 30, 1049-1057.

[9] Z. Nawaz, X. P. Tang, Y. Chu, F. Wei, Chin. J. Catal., 2010, 31, 552-556.

[10] Y. W. Zhang, Y. M. Zhou, J. J. Shi, S. J. Zhou, X. L. Sheng, Z. W. Zhang, S. M. Xiang, J. Mol. Catal. A, 2014, 381, 138-147.

[11] G. D. Angel, A. Bonilla, Y. Peña, J. Navarrete, J. L. G. Fierro, D. R. Acosta, J. Catal., 2003, 219, 63-73.

[12] M. S. Kumar, D. Chen, A. Holmen, J. C. Walmsley, Catal. Today, 2009, 142, 17-23.

[13] Y. W. Zhang, Y. M. Zhou, H. Liu, Y. Wang, Y. Xu, P. C. Wu, Appl. Catal. A, 2007, 333, 202-210.

[14] Y. Chu, B. S. Zhang, Q. Zhang, Y. Wang, D. S. Su, F. Wei, Micropor. Mesopor. Mater., 2013, 169, 201-206.

[15] S. A. I. Barri, US Patent 5118 483, 1992.

[16] D. B. Lukyanov, V. L. Zholobenko, J. Dwyer, S. A. I. Barri, W. J. Smith, J. Phys. Chem. B, 1999, 103, 197-202.
[17] S. Jiang, Y. K. Hwang, S. H. Jhung, J. S. Chang, J. S. Hwang, T. X. Cai, S. E. Park, Chem. Lett., 2004, 33, 1048-1049.

[18] A. Subbiah, B. K. Cho, R. J. Blint, A. Gujar, G. L. Price, J. E. Yie, Appl. Catal. B, 2003, 42, 155-178.

[19] M. S. Kumar, A. Holmen, D. Chen, Micropor. Mesopor. Mater., 2009, 126, 152-158.

[20] Y. W. Zhang, Y. M. Zhou, K. Z. Yang, Y. A. Li, Y. Wang, Y. Xu, P. C. Wu, Micropor. Mesopor. Mater., 2006, 96, 245-254.

[21] T. A. Peters, O. Liron, R. Tschentscher, M. Sheintuch, R. Bredesen, Chem. Eng. J., 2016, 305, 191-200.

[22] Y. W. Zhang, Y. M. Zhou, A. D. Qiu, Y. Wang, Y. Xu, P. C. Wu, Catal. Commun., 2006, 7, 860-866.

[23] H. L. Zhou, Y. J. Wu, W. Zhang, J. Wang, Mater. Chem. Phys., 2012, 134, 651-656.

[24] M. Ghiaci, F. Seyedeyn-Azad, R. Kia, Mater. Res. Bull., 2004, 39, 1257-1264.

[25] Z. S. Xu, T. Zhang, Y. N. Fan, L. W. Lin, Stud. Surf. Sci. Catal., 1997, 112, 425-432.

[26] K. P. Wendlandt, H. Toufar, B. Unger, W. Schwieger, K. H. Bergk, J. Chem. Soc. Faraday Trans., 1991, 87, 2507-2513.

[27] M. A. Asensi, M. A. Camblor, A. Martínez, Micropor. Mesopor. Mater., 1999, 28, 427-436.

[28] Y. Z. Duan, Y. M. Zhou, X. L. Sheng, Y. W. Zhang, S. J. Zhou, Z. W. Zhang, Micropor. Mesopor. Mater., 2012, 161, 33-39.

[29] N. Katad, K. Suzuki, T. Noda, M. B. Park, H. K. Min, S. B. Hong, M. Niwa, Top. Catal., 2010, 53, 664-671.

[30] C. L. Yu, H. Y. Xu, Q. J. Ge, W. Z. Li, J. Mol. Catal. A, 2007, 266, 80-87. 
[31] R. Contreras, R. Cuevas-García, J. Ramírez, L. Ruiz-Azuara, A. Gutiérrez-Alejandre, I. Puente-Lee, P. Castillo-Villalón, C. Salcedo-Luna, Catal. Today, 2008, 130, 320-326.

[32] P. Dejaifve, J. C. Vedrine, V. Bolis, E. G. Derouane, J. Catal., 1980, 63, 331-345.

[33] D. Kolb, J. Chem. Educ., 1978, 55, 459-464.

[34] J. Salmones, J. A. Wang, J. A. Galicia, G. Aguilar-Rios, J. Mol. Catal. A, 2002, 184, 203-213.
[35] A. Vázquez-Zavala, A. Ostoa-Montes, D. Acosta, A. Gómez-Cortés, Appl. Surf. Sci., 1998, 136, 62-72.

[36] O. A. Bariås, A. Holmen, E. A. Blekken, J. Catal., 1996, 158, 1-12.

[37] W. S. Yang, R. A. Wu, L. W. Lin, J. Fuel Chem. Technol., 1991, 19, 200-207.

[38] W. S. Yang, R. A. Wu, L. W. Lin, J. Fuel Chem. Technol., 1991, 19, 312-319.

\title{
PtSnNa/SUZ-4: 丙烷脱氢反应的高效催化剂
}

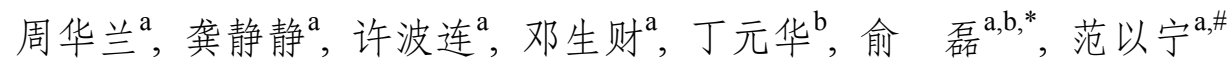 \\ a南京大学化学化工学院介观化学教育部重点实验室, 江苏南京 210093 \\ b扬州大学化学化工学院江苏省环境材料与环境工程重点实验室, 江苏扬州 225002
}

\begin{abstract}
摘要: 丙烷脱氢制丙烯是优化利用炼厂气和油田伴生气资源的一条重要途径. 随着丙烯需求量的逐步增加, 丙烷脱氢制丙 烯日益受到重视. 负载型 $\mathrm{PtSn} / \gamma-\mathrm{Al}_{2} \mathrm{O}_{3}$ 催化剂具有优良的丙烷脱氢活性和选择性, 但在高温、低氢压的反应条件下, 催化剂 易积炭而失活. 近年来, 选用了微孔分子篮如ZSM-5和介孔分子篮如SBA-15和MCM-41作为PtSn催化剂的载体, 结果表明, 具有规整孔道结构的负载型 $\mathrm{PtSn} /$ 分子篮催化剂的丙烷脱氢反应稳定性明显优于 $\mathrm{PtSn} / \gamma-\mathrm{Al}_{2} \mathrm{O}_{3}$ 催化剂. SUZ-4分子篮与 ZSM-5 分子篮结构相似且孔径相当, 所不同的是ZSM-5 由十元环交叉孔道组成, 而SUZ-4由十元环和八元环孔道垂直相交 组成. 我们用微型催化反应装置结合XRD、BET比表面积和孔体积测试、 $\mathrm{NH}_{3}$ 吸附-程序升温脱附 $\left(\mathrm{NH}_{3}-\mathrm{TPD}\right)$ 、氢化学吸附、 热重分析 $(\mathrm{TG}) 、 \mathrm{H}_{2}$ 程序升温还原 $\left(\mathrm{H}_{2}-\mathrm{TPR}\right)$ 和程序升温氧化(TPO)等多种物理化学手段研究了负载型 PtSnNa/SUZ-4和 PtSnNa/ZSM-5催化剂的结构和丙烷脱氢反应性能, 以及这两种催化剂在丙烷脱氢反应中催化性能差异的原因.
\end{abstract}

实验结果显示, 在丙烷脱氢反应中, 负载型PtSnNa/SUZ-4催化剂上丙烯选择性和反应稳定性明显优于PtSnNa/ZSM-5催 化剂, 说明载体一定程度上会影响催化剂上丙烷脱氢反应性能. XRD, BET比表面积和孔体积测试等表征手段结果表明, SUZ-4和ZSM-5的孔体积和比表面积比较接近, 载体的结构又类似, 且两者的积碳量也相近, 故载体的基本性质和积碳量的 差异不是引起催化剂性能差异的原因. $\mathrm{NH}_{3}$-TPD结果表明, H-SUZ-4的酸强度明显强于H-ZSM-5. 由于浸渍法制备负载型 $\mathrm{PtSn}$ 催化剂所用前体为具有强酸性的混合溶液 $\left(\mathrm{H}_{2} \mathrm{PtCl}_{6}+\mathrm{SnCl}_{4}\right)$, 存在于 $\mathrm{SUZ}-4$ 分子篮孔道内表面的强酸中心不利于上述前 体与SUZ-4分子篮孔道内表面结合. ZSM-5分子篮孔道内表面比较弱的强酸中心, 促进了催化剂前体在ZSM-5分子筛孔道 内表面的分散与结合. 和ZSM-5 为载体的催化剂相比, PtSnNa/SUZ-4上Pt粒子大部分分散在载体的外表面, 从而金属上的 积碳不易引起催化剂的失活. 故多孔材料上Pt的分布是影响催化活性差异的主要原因.

为进一步证明多孔材料上Pt的分布是影响催化活性差异的主要原因, 我们通过二苯并噻吩预处理催化剂的手段证明 $\mathrm{Pt}$ 粒子在分子篮孔内外的分布情况. 由于二苯并噻吩的尺寸比较大 $(0.8 \mathrm{~nm})$ 不能进入到分子篮的孔道内(SUZ-4:0.56 nm, ZSM-5:0.56 nm), 所以载体孔道外的部分Pt会被二苯并噻吩预处理而失去活性, 而孔道内的Pt不会因为预处理仍具有催化 活性. 实验结果表明, PtSnNa/SUZ-4经过二苯并噻吩预处理后, 催化活性大大降低; 而PtSnNa/ZSM-5 经过二苯并噻吩预处 理后, 催化活性几乎没有变化. 说明 PtSnNa/SUZ-4上Pt粒子大部分分散在载体的外表面, 从而金属上的积碳不易引起催化 剂的失活.

关键词: SUZ-4分子篎; 铂锡钠催化剂; 丙烷脱氢反应; 催化剂稳定性; Pt的分布

收稿日期: 2016-11-16. 接受日期: 2016-12-17. 出版日期: 2017-03-05.

*通讯联系人. 电话: 13665295901; 传真: (0514) 87975244; 电子信箱: yulei@yzu.edu.cn

\#通讯联系人. 电话: (025)83594620; 传真: (025) 83317761; 电子信箱: ynfan@nju.edu.cn 基金来源：江苏省博士后科研资助计划 (1301080C), 国家自然科学基金(21202141, 21173182), 扬州关键科技特定项目 (YZ20122029), 扬州大学创新培育基金(2015CXJ009).

本文的英文电子版由Elsevier出版社在ScienceDirect上出版(http://www.sciencedirect.com/science/journal/18722067). 